\title{
The Ethical Dimension in Transformational Leadership
}

\author{
Anona Armstrong \\ Victoria University, Australia \\ Nuttawuth Muenjohn \\ RMIT University, Australia
}

\begin{abstract}
Few empirical studies have been done that directly address the underlying values that drive leadership or distinguish its ethical dimensions. As a result the development of a theory about how values and ethics affect transformational leadership lacks empirical support. This has important implications for the study of transformational leadership. The purpose of this study was to establish a range of values and implied approaches to ethics that are associated with transformational styles of leadership, to use an inductive approach to determine the values and ethical approaches associated with transformational leadership, and to determine whether such a style is always right in itself. The study used interview data from senior executives to address the questions: What kinds of values do people associate with the dimensions of transformational leadership? Are these values related to ethical conduct and positive outcomes for followers and organisations? What are the values that drive transformational leadership behaviour? Is there an ethical or moral dimension to it? Do these represent ethical or immoral dimensions in the "Full range leadership model? The results of this study suggest that leaders' values are more important in driving ethical behaviour among leaders, than the operationalisation of the management practices suggested by transformational leadership theory,
\end{abstract}

\section{Keywords}

Ethics, Values, Ethical Leadership, Transformational Leadership Introduction

\section{Introduction}

Prior to discussing this study, it is important to set the context of the present study by a review of some of the traditional approaches to understanding leadership, the development of transformational leadership and its dimensions, and how various researchers suggest that an ethical dimension supported by values provides the underlying principles that set acceptable standards and criteria for the ethical behaviour of individual transformational leaders. The next section defines different categories of values and four traditional ethical theories. The paper argues that if transformational leadership has an ethical dimension then leaders using a transformational leadership style should exhibit the values and

Copyright (C) 2008 Victoria University. This document has been published as part of the Journal of Business Systems, Governance and Ethics in both online and print formats. Educational and non-profit institutions are granted a nonexclusive licence to utilise this document in whole or in part for personal or classroom use without fee, provided that correct attribution and citation are made and this copyright statement is reproduced. Any other usage is prohibited without the express permission of the behaviours that are compatible with the ethical theories. The final section describes the research methodology and discusses the results of the findings.

Personality traits, although found to relate to leadership (Stoghill, 1974), have not always been good predictors of good leaders. Most theories of leadership have in fact shied away from looking at personality. 
After all if leadership could be learned, (and it was not an inherent part of personality), there was a role for academia in teaching it. So, academics concentrated on different dimensions in the management styles of leaders such as an orientation towards achieving tasks and/or relationships with people (Blake and Mouton, 1985). A difficulty with these models was that researchers were unable to associate the behaviours of leaders with outcomes such as morale, job satisfaction and productivity. It also seemed that different situations demanded different kinds of leadership. Situational models examined the demands of the situation in which leadership occurred (Hersey and Blanchard, 1993). Contingency theory was another well researched approach bringing together elements of both leadership style theory and the influence of the situation in which leadership was exhibited. An example was Feidler's (1967) contingency model which suggests that situations can be characterized by assessing three factors: leader-member relations (confidence, loyalty and attraction that followers feel for their leader, (b) clarity of a task structure or requirements, and (c) position power or authority of a leader. Combinations of the three variables predicted the preferred leadership style in different situations. (Northouse, 2001). The most favourable situations are those having good leader-follower relations, defined tasks, and strong leader position. This theory was useful in describing the appropriateness of using leaders with different styles in different situations, but did not explain why this was so.

Some conclusions from these leadership models were that all of the elements, personality traits, the situation, leader member relations, and power, have an influence on the practice of leadership. In response, Bass and Avolio, (1997) developed a "Full Range of Leadership model" to include all of these elements. Their model proposes three types of leadership behaviour: laissez-faire or no leadership, transactional leadership, and transformational leadership.

Laissez-Faire represents the absence of leadership. The leader abdicates responsibility, delays decisions, gives no feedback, and makes little effort to help followers to satisfy their needs. An example would be the Managing Director of a firm who calls no meetings with the firm's managers, has no long range plans for his or her company and makes little contact with employees within the organisation.

Transactional leaders exchange things of value with subordinates to advance their own as well as their subordinates' agenda. Political leaders who win votes by promising no new taxes are demonstrating transactional leadership. Similarly, managers who offer bonuses to employees based on their performance are exhibiting transactional leadership. Bass and Avolio distinguish three components of transactional leadership: management-by-exception in an active form, (involving corrective criticism, negative feedback, and negative reinforcement such as when a leader closely watches followers to find mistakes or rule violations); management-by-exception passive when intervention occurs only after problems arise; and contingent reward which occurs when a leader tries to negotiate with a follower what needs to be done to get what payoffs. Northouse (2001) gives the example of the latter in an academic setting when a dean negotiates with a professor the number of publications that he or she needs in order to receive tenure and promotion.

In contrast to transactional leadership, transformational leaders are people who:

Attempt and succeed in raising colleagues, subordinates, followers, clients or constituencies to a greater awareness about issues of consequence. This heightening of awareness requires a leader with vision, self-confidence, and inner strength to argue successfully for what is right or good, not for what is popular or is acceptable according to established wisdom of time"(Bass, 1985, p. 17).

The four transformational leadership factors are described as (Northouse, 2001):

- Idealized Influence describes leaders who are change agents, set standards and vision and act as strong role models for followers. They are deeply respected by followers, who identify with them and usually place a great deal of trust in them.

- Inspirational Motivation describes leaders who communicate high expectations to followers, inspiring them through motivation to become committed to and a part of the shared vision in the organisation. 
- Intellectual Stimulation is a style of leadership that stimulates followers to be creative and innovative, and to challenge their own beliefs and values as well as those of the leader and the organisation.

- Individualized Consideration represents leaders who provide a supportive climate in which they listen carefully to the individual needs of followers. Leaders act as coaches and advisers while trying to assist individuals become fully actualised.

Research into transformational leadership suggests that it is perceived to be more effective than transactional leaders, and is related to better work outcomes, satisfaction of followers. Furthermore, its dimensions are relevant across cultures (Muenjohn and Armstrong, 2001, 2007,2008; Boehnke et al 2003), that is, transformational leadership appears to have universal application.

A strength of transformational leadership is the wealth of research that supports the existence of the dimensions. It is seen as a process that incorporates the action of both leaders and followers in satisfying the needs of both, and supporting the development of a continuous path towards higher standards of moral responsibility. It includes motivating followers to transcend their own self-interests for the good of the team, organisation, or community (Muenjohn and Armstrong, 2008). In particular, Avolio and Bass 1995, p.202) suggest, in regard to the dimension of Individualized Consideration, "Individualized Consideration may concentrate on changing followers' motives, moving them to consider more than their self-interest but also the moral and ethical implications of their actions and goals".

Elliott $(2002,2004)$ explored this ethical component in transformational leadership in a number of studies. He said (Elliott, 2002, p.31) that transformational leadership enables "adaptation to change, empowerment, the achievement of potentials, and high levels of motivation and commitment". It encourages followers to develop to their fullest potential and indeed "exceed performance expectations by ethical and appropriate impression-management behaviours which engender trust and commitment".

Some of the critics of the model suggest that transformational leadership theory based on data collected from leaders at the top of organisations may not necessarily apply to leaders within an organisation. Others claim that transformational leadership is elitist and antidemocratic because transformational leaders take a direct role in creating changes, establishing directions, creating the vision and that this "gives a strong impression that a leader is acting independently of followers or putting himself or herself above followers' needs" (Northouse, 2001,p.147). Allied with this is the fear that transformational leaders, especially charismatic leaders, may prey on followers and manipulate them. As Howell and Avolio (1992) suggest, the same qualities that make great leaders can also lead to unethical behaviour. Rather than motivating followers to pursue higher ideals, leaders may in fact lead followers in negative, unethical and immoral directions (Giampetro, Brown, Browne, \& Kubasek, 1998; Parry \& Proctor, 2001; Yukl, 1998). Reports in the press of company directors' misuse of funds, insider trading, and unconscionable conduct are indicative of a lack of ethical integrity among some business leaders.

Bass (2000) addressed some of the criticism by making a distinction between authentic transformational leadership, which is seen as ethical, and pseudo-transformational leadership which may be a pose by a leader who practices transformational leadership behaviour but in fact is motivated by meeting selfserving interests. Bass and Steidlmeir (1999) suggest that values provide the underlying principles that set acceptable standards and criteria for the ethical behaviour of individual transformational leaders. They argue that while pseudo-transformational leaders use moral persuasion but their motivation is power and personal gain authentic transformational leaders are motivated by acceptable values and ethics.

This distinction has stimulated a growing discussion about the ethics of transformational leaders. Leaders who are transformational have an undoubted influence on the values of followers and play a major role in establishing the values and ethical climate exhibited by an organisation (Cockerell and Armstrong 1998). Because of their influence and power, they have an ethical responsibility for how they affect other people. 
Research into transformational leadership (Kuhnert, 1994; Parry \& Proctor, 2001) indicates that individuals who exhibit transformational leadership have a strong set of internal values and ideals, and are effective in motivating followers to act in ways that support the greater good rather than their own self interests.

Values are defined as the beliefs and principles individuals use to guide their actions, behaviours, and judgments of what is right or wrong, and the selection of the social goals or ends that are desirable. Something valued is considered worthwhile, good, desirable, important, and esteemed or prized. Something that is valueless is considered to be worthless.

Sarros and Butchatsky (1996, p.12 ) in referring to the difference between values and beliefs said: "Beliefs are basic assumptions about the world and how it works, and they guide our behaviour in terms of underlying principles. For instance, we believe that money is a motivator, and act accordingly. Values are basic assumptions as are beliefs. But values are assumptions that are normative. That is, what we believe is of worth, and should actively pursue and represent in our actions and behaviours. A belief represents the information a person has about an object and links an object to some attributes (Fishbein and Ajzen, 1975). The object of the belief may be a person, a group of people, an institution, a behaviour, a policy, an event, etc., and the associated attribute may be any object, trait, property, quality, characteristic outcome or event. Beliefs may not determine actions as much as do values .

A set of governing values might include how leaders behave with others, or what is expected of others. They could include fairness, justice, honesty, freedom, equality, loyalty, self-fulfillment, courtesy, and cooperation.

Values are important to leaders because they influence preferences and aspirations. It is alignment of the values of leaders and followers that allows leaders to exert influence that in transformational leadership leads to changes in behaviours. Lagen (1998, p.28) states "a shared values system can energise an organisation and meld a disparate group into a self-organising community. For those who get it right, management by values renews employee morale as control give way to a more flexible and trusting environment-the ideal conditions from which high-performing workplace cultures emerge"

Various researchers have attempted to explain the differences found in national cultures through preferences for different value systems (Feather, 1986; Hamden-Turner \& Trompenaars, 1993; Hofstede, 1980) Hamden-Turner and Trompenaars argue that values drive business behaviour and that different cultures produce and develop effectively that which is most valued. Among the values of western cultures is the value of competition in the market place. They suggest that a loss of respect for "values" is at the heart of the moral crisis of western society. Values have been devalued because of the emphasis on science, which declared itself "value free". (They ask: when is scepticism not a value?)

Rokeach (1973) differentiated values into two kinds, 18 terminal values concerned with desired end states, and 18 instrumental concerned with modes of conduct divided into moral and competence values. Terminal values were grouped into personal-oriented category (a comfortable life, an exciting life, a sense of accomplishment, etc) or an interpersonal (or social) category (a world at peace, a world of beauty, equality, national security). Instrumental values or what Rokeach refers to as a "mode of conduct" can be further divided into those which have a competence value orientation (ambition capable, imaginative, independent, intellectual logical, responsible and those with a moral value orientation (cheerful, clean, courageous, forgiving, helpful, honest, loving, obedient, polite). Moral values "have an interpersonal focus which, when violated, arouse feelings of guilt for wrongdoing" (Rokeach, 1973, p.8). Competence values, however, "have a personal rather than an interpersonal focus and do not seem to be especially concerned with morality. Their violation leads to feelings of shame about personal inadequacy rather than to feelings of guilt about wrong-doing "(1973, p.8).

Francis (2000, p.10) distinguishes between ethics, morals and values:

The terms ethics and morals are sometimes used interchangeably, although one can make distinctions (the word ethics is from Greek, whereas the word morals is from Latin). More commonly, 'morals' refers to the standards held by the community, often in a form not explicitly 
articulated. 'Ethics', on the other hand, concerns explicit codes of conduct as well as value systems... Ethics is a highly explicit codified form of behaviour designed to produce particular ends and act in accordance with particular values. There are admirable values (such as wealth or success); there are other values that are of direct concern (such as honesty or fairness).

Ethics concern the actions and practices that are directed at improving the welfare of society, determining what is good or right for human beings and society, what goals people and society ought to pursue and what actions they ought to perform. Individuals draw on their experiences with others in determining the rules that ought to govern human behaviour and the values worth pursuing. Hence, the study of ethics is a systematic attempt to make sense of the reasoning that people apply when making decisions and questioning the values and rules of our society.

Four major types of ethical philosophical theories are virtue ethics, egoism, teleology and deontology. Virtue ethics is based on the idea that morality is primarily about virtue or character and that people of good character are more likely to make right decisions, so ethics should concentrate on moral development (Elliott \& Engebretson, 2001). Ethical egoism is a theory that states that an individual should follow the greatest good for oneself. People who use an egoistic criterion to make ethical decisions are exclusively concerned with self-interest, the central posit of pseudo-transformational leadership. Comparing deontology and teleology: deontology concentrates on the correctness of the intentions of the decision maker and the means chosen to accomplish a task, and teleology concentrates on the consequences of actions. Deontological theories address duty and moral obligation, which are met by satisfying the legitimate claims or needs of others. Teleological theories, such as utilitarianism, emphasise the greatest good and minimal harm for the greatest number. While egoism is seen as being immoral, the other two theories promote ethical values that could be seen to be consistent with authentic transformational leadership.

Although research into transformational leadership suggests that it has a moral dimension,, the relationships with leaders' values are unclear. Few empirical studies have been done that directly address the underlying values that drive transformational leadership or distinguish its ethical dimensions. As a result the development of a theory about how values and ethics affect transformational leadership lacks empirical support. This has important implications for the study of transformational leadership and raises the questions of: What are the values that drive leadership behaviour? Is there an ethical or moral dimension to it? Are values reflected in behaviours represented in the "mode of conduct" as Rokeach (1973) suggests? Do these represent ethical or immoral dimensions in the "Full range leadership model?

\section{Theoretical framework}

The theoretical framework for the study is shown in figure 1. If transformational leadership has an ethical dimension then leaders using a transformational leadership style should exhibit the values and behaviours that are compatible with the ethical theories. The framework assumes that the values identified will have characteristics which allow them to be categorized along the Rokeach (1979) dimensions of terminal and instrumental values. It should be noted that these are espoused values as they are the values reportedly shown by experienced leaders. The enacted or values-in-use are illustrated by the ethical behaviours demonstrated in the practice of transformational leadership.

The model (Figure 1) assumes that determining values will influence the practice of transformational leadership, that this will lead to ethical or unethical conduct, and that such conduct will produce positive or negative outcomes for individuals and an organisation.

This study attempted to identify the implicit values that are associated with leadership, the behaviours associated with the four dimensions of transformational leadership and some effects associated with the four transformational leadership styles.

The research questions were: 
- What kinds of values do people associate with the dimensions of transformational leadership?

- Are these values related to ethical conduct and positive outcomes for followers and organisations?

- What are the values that underlie ethical leadership?

Figure 1. Theoretical Framework

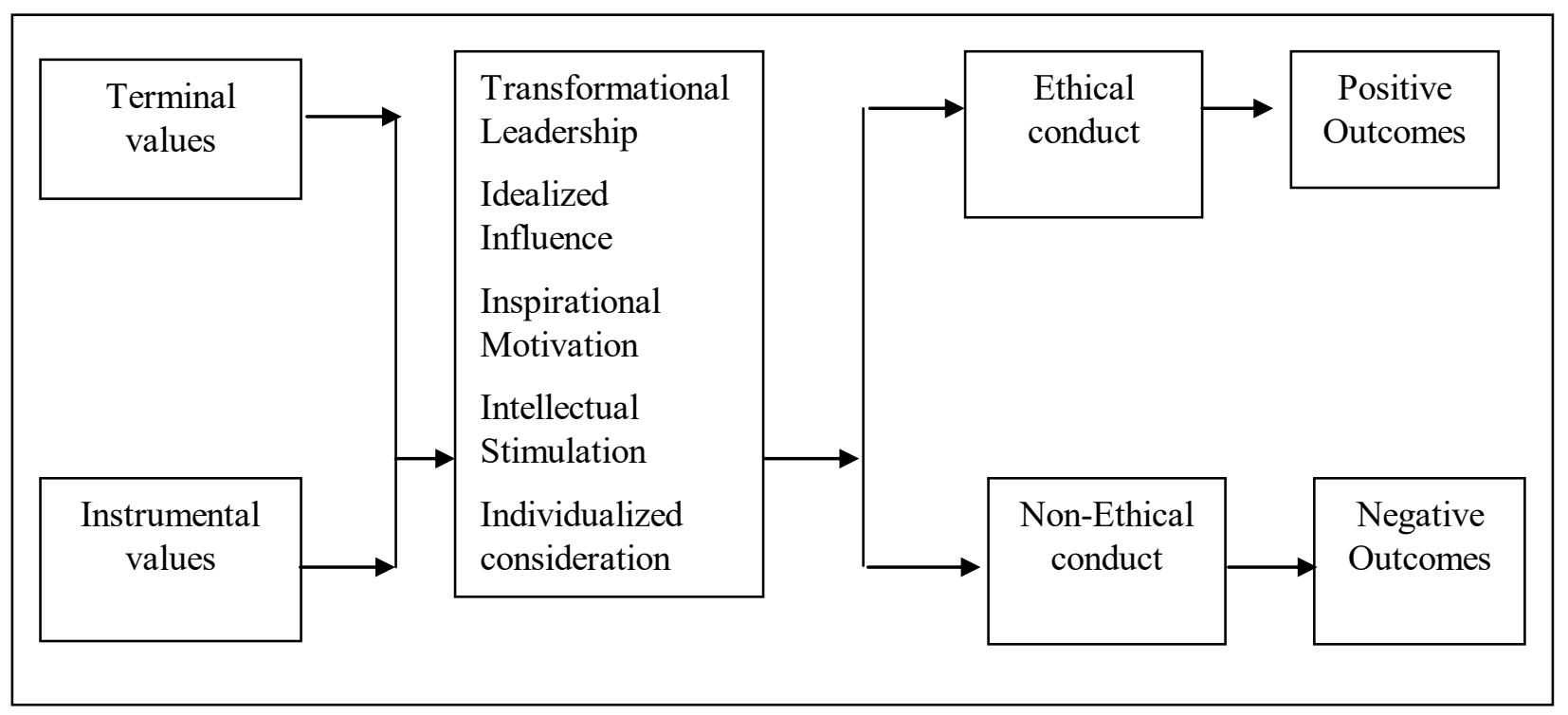

\section{Method}

The purpose of the study was to establish a range of values and implied approaches to ethics that are associated with transformational styles of leadership, to use an inductive approach to determine the values and ethical approaches were associated with transformational leadership, and to determine whether such a style is always right in itself.

The study reported here is one of three studies undertaken as part of a larger study by three researchers using a triangulation design to address similar issues (Elliott, Armstrong, \& Alder, 2001). Ray Elliott (undertaking item analysis) and John Alder (analyzing focus groups) are responsible separately for other parts of the overall research design. Triangulation has been identified as a means to enhance the validity of research findings of complex and multifaceted phenomena such as leadership (Herman \& Egri, 2002). In this arm of the research interviews supported a grounded theory approach to data collection and analysis.

Roberts (2002) suggests that in a "grounded" theory approach practitioners are best placed to make sense of the realities they experience. Researchers have the abilities to make sense of meaningful lived experiences and to contribute to knowledge by combining reflection with the generation of ideas from understanding of the phenomenon being studied. This present study contributes to the development of a theory that is yet to articulate the relationships between values, ethics and transformational leadership.

Despite awareness of the previous research that categorized values, an inductive approach was preferred so as to allow the data to drive the development of the theory rather than a deductive approach in which the theory shapes the collection of data. As Dubin $(1978$, p.18) states "descriptions of the real world are essential points of origin for theories in applied areas like industrial psychology, if not in all areas.... Any generalization that starts from the data points generated by observation and description is arrived at through an inductive process". He argues (p.19) that organisational psychologists are forced to start with induction theory because the discipline involves investigation of "men of affairs- who usually 
possess a good descriptive knowledge of their affairs and can test our theorizing against the real world they know". From the data conclusions and hypotheses can be drawn which can then be tested using a deductive process.

The method in this study was to develop a framework based on the search of previous literature, select a sample of recognised leaders, develop an interview schedule of open ended questions, and conduct interviews with the respondents. The respondents were 10 leaders ( 2 female, 8 male) from industry, academia, and politics. Ethics approval was obtained from Victoria University's Human Ethics Committee and confidentiality assured to participants. An open ended interview approach was designed to overcome the problems associated with interviewer involvement and bias, and to allow the emergence of responses unbiased by the structure of the questions asked. The respondents were asked to recall examples of the four transformational leadership styles, to give examples of leadership decisions that would demonstrate the four styles, to identify the key values reflected in each of the examples and evident in the best and worst leadership behaviours, and the associated implied approach to ethics.

A purposive and convenience sampling approach was used in which eleven people recognised as senior leaders in their fields (politics, law, education and business) were invited to participate. It is likely that people who are experienced leaders will be more knowledgeable about what drives their behaviour and they are also important in the maintenance and transmission of values within their organisations.

A content analytic approach for comparing values has been widely used (Lasswell, et al 1952; Kabanoff and Daly, 2000). The approach used in this study categorized the concepts according to (a) the Rokeach categories of values; (b) the four dimensions of transformational leadership and (c) the reported values and outcomes associated with leadership behaviours.

\section{Results}

Reported below are the respondents' perceptions of the results of experiencing the worst leadership styles, i.e. the perceptions of the values motivating this kind of behaviour, the behaviours exhibited and the outcomes for leaders and follower; positive and negative outcomes associated with each of the four transformational dimensions, the values associated with transformational leadership, the relationship of the values to ethical theory and how the findings relate to the propositions inherent in the theoretical framework described above. The items in tables 1-5 are the reports from respondents.

\section{Positive and negative outcomes associated with the four transformational dimensions}

Respondents were asked to identify the effects associated with the best and worst leadership styles and then to identify the key values associated with the best and worst leadership practices and the implied approach to ethics. Table 2 reports how respondents perceived the positive outcomes from transformational leadership.

Idealized Influence resulted in high standards of performance, and reciprocal feelings of happiness and confidence between the leader and followers. A good leader must be competent in the true sense, setting goals, and providing the 'cause'. Their high levels of passion and energy draw people to them.

Inspirational Motivation was seen as stretching and challenging followers to perform at their full potential when followers were empowered, but being demotivating when it was exhibited as bullying people to take responsibilities they may not want. One respondent described the mutual satisfaction experienced when he gave an officer in a department a task of implementing or working out how to implement a practical goal rather than telling them how to do it. The success of this dimension was also dependent on transparency and having the infrastructure to support the initiatives.

The success of Intellectual Stimulation depended on the competence of both the leader and employee. There needed to be a balance and agreement about what should be challenged and how. One leader reported as his common practice to develop a position, ask for comment, and assess the objections. 
Individualized Consideration, operationalisation as promoting individual development, was seen to be a positive outcome. Most successful were the leaders who try to bring out the qualities of all, not just a few. Respondents saw this demonstrated by referring to situations where there were many disparate positions Leaders demonstrated this dimension through the way work was allocated so that people could operate in an area that allowed them to productively use their skills and were encouraged to venture into new horizons. An associated practice was to give people a task to accomplish and then let them work out how to implement a practical goal rather than being told how to do this. A major issue is how the leaders deal with mistakes by themselves as well as subordinates. Admission of mistakes, forgiveness and using a 'carrot' was seen to be a better practice than punishment. This approach, as was "needing a sense of humour", was also seen to be ethical.

\section{The Limitations of Transformational Leadership}

Responses to the issue of whether transformational leadership is always the "right" leadership style drew a number of criticisms and negative perceptions (Table 4).

Idealized Influence sets and portrays the standards and vision for reference and/or the inspiration of staff. It has limitations when the vision is wrong and/or bad or too domineering. Negative effects associated with Idealized Influence were the inappropriateness of this kind of leadership to some people, that it could be seen as distant from followers and lacking flexibility to motivate followers in other ways. Leaders strong in this dimension could also be seen as 'distant' and ignoring the possibilities for accomplishing a goal in another way. Finally, it could be ineffectual if there was not the supporting infrastructure to enable leaders to deliver promises, or inappropriate if it was exercised for a bad cause, examples being leaders such as Hitler or leaders instigating a prison revolt.

Inspirational Motivation encourages participation and empowerment. On the one hand this takes time and some managers would see it as losing control or not meeting their responsibilities. On the other it may be unsuitable for some followers who prefer to be 'told' and seek direction. Inspirational Motivation was not always appropriate as circumstances arose on occasions when decisions had to be made without consultation. "People who can't live up to the standards can be bullied into a common mould". One respondent thought that "empowerment" was an abused term more likely to be interpreted as abrogation

Intellectual Stimulation is the process in which leaders are supposed to present clear directions while allowing challenge and contradiction. The downside is perceptions of a weak leader without credibility and this style can only work in a supportive culture. Intellectual Stimulation that produced wise delegations that were effective. However, people must be particularly courageous to challenge their leaders and there were dangers in contradicting leaders who could find challenges difficult to cope with. The leader needs to have listening skills, not criticize or challenge views, and have a supporting culture in which to operate; otherwise challenges in groups are likely to disintegrate into conflict situations. Teams can be sidetracked into achieving activities such as forming alliances rather than the performance of the team task. Further, some followers prefer more harmony and a consensus style of decision making.

The success of Individualized Consideration, the fourth dimension, in which followers' individuality is promoted, depended too much on the competence of the leader to judge each follower's skills and abilities and assumes that the leader has the time available and the ability to recognize differences in abilities between people. In this case, teamwork was seen as more important than individual activities. In many situations leaders faced with opposition can develop favorites. Alternatively, when people do not want to be "developed", difficulties arose in knowing what leaders could do with them. 


\section{Values, behaviours and outcomes associated with the worst leadership styles}

Respondents had no difficulty describing the values that influence the behaviours of the worst leadership styles (Table 2) as a desire for control, greed, disregard of people's welfare and an absence of ethical principles. Behaviours ranged from the extreme ends of a dimension of imposing controls to lack of willingness to make decisions. As a result leaders experienced egomania, lack of support from followers, and an atmosphere of conflict, infighting and uncertainty generating stress. The impact on followers ranged from anger and despair to non-cooperation and eventually leaving an organization.

Figure 2. Confirmation of the Theoretical Framework

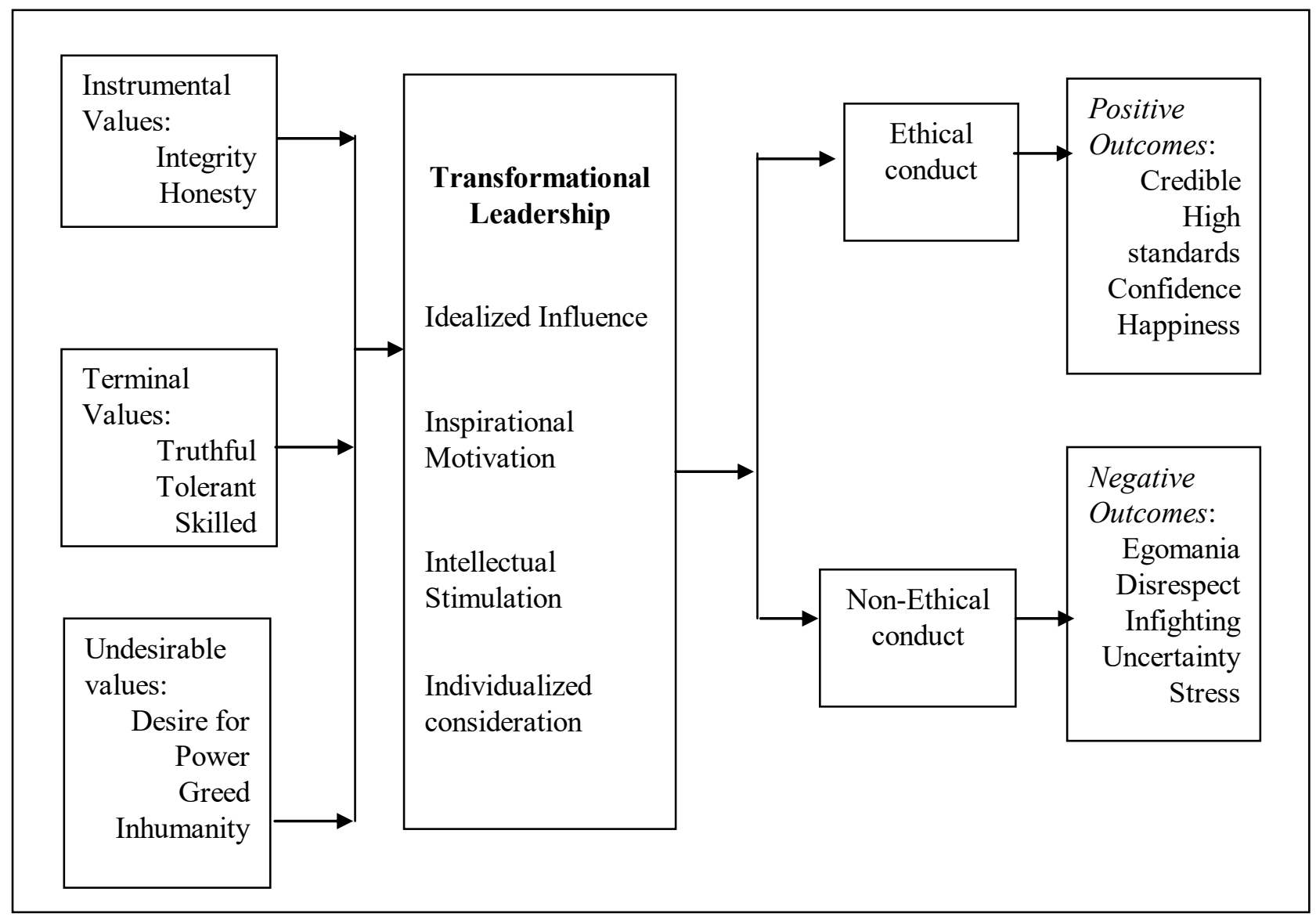

\section{The Terminal and Instrumental Values Associated with Transformational Leadership}

The answers to the questions asking respondents to identify the values associated with the best leadership styles, and with transformational leadership in particular are categorized in table 3 into the two types of values identified by Rokeach (1973), instrumental and terminal.

Instrumental values included integrity, honesty, caring, fairness, respect for people, and other personal attributes such as truthfulness, calmness, hopeful, confident, risk taking and fearless. Terminal values were self-worth, respect, dignity, pride, justice, equity, and personal competencies shown as clarity of mind, interpersonal skills, love and respect for life.

Rokeach (1973) argued that those values indicating a moral dimension were instrumental values that had an interpersonal focus which when violated arouse a sense of guilt or wrongdoing. The instrumental values reported by the responding leaders to be associated with transformational leadership and categorized in Table 3 are similar in many respects but have the additional values added to include "caring, understanding the needs of others", "not doing things in your own interest", "able to hold 
conflicting views", "not needing to agree with others", "transparent", "risk taking" and "fearless". Although it could be argued that these values could be categorized differently, there is nevertheless, considerable overlap with the values of integrity, honesty, etc that Rokeach identified as reflecting a moral dimension.

\section{What are the Values that Underlie Ethical Transformational Leadership?}

The final research question was "What are the values that underlie ethical leadership?" In Table 5, values identified as instrumental and terminal values associated with positive aspects of transformational leadership are categorized into the three dimensions associated with the three ethical theories identified above. Egoistic theory is about the self-interest of the leader. Some of the values, which are of worth to a leader, could include instrumental values such as honesty with self and terminal values such as personal happiness, dignity and pride. Teleological theories are concerned with the outcomes achieved.

Here, truthfulness, tolerance and politeness are some of the instrumental values and equity, justice and respect for life are some of the end states that leaders could hope to achieve. Deontology is about principle, duty and rules, it the 'means' of achieving the outcomes. In this case, examples of the instrumental values associated with transformational leadership are caring, and commitment to ethical behaviour, which are required to achieve understanding, love and respect for life.

\section{Discussion}

Figure 2 summarizes the results of the study. The study showed that leaders held both positive and negative values, and both kinds of values could be associated with transformational leadership. The negative values were most likely to be associated with unethical conduct and produce negative outcomes. In contrast, where positive values were held, the behaviour of leaders was likely to be associated with the instrumental and terminal values identified by Rokeach (1973) and to produce positive outcomes for both leaders and followers.

In response to the research questions: What kinds of values do people associate with the dimensions of transformational leadership? Negative values included desire for control/power at all cost, greed, and disregard of people's welfare. Positive values included integrity, honest, caring, and truthfulness, tolerance, personal control. Are these values related to ethical conduct and positive outcomes for followers and organisations? The results were unambiguous. Leaders who held positive values achieved high standards, happiness, and feelings that work was worthwhile. Leaders who exhibited negative values produced anger, despair, non-cooperation and lack of commitment.

What are the values that underlie ethical leadership? The positive values that are associated with the positive aspects of transformational leadership demonstrate the type of values that support the three ethical theories of egoism, teleology and deontology. Although egoism is often associated with selfserving interests, it could be argued that values such as honesty with oneself, and aiming for personal happiness, dignity and pride although self-centered are not undesirable endstates. It is when negative values are associated with self-serving interests to the exclusion of others' rights and interests that egoism is undesirable. Positive values of truthfulness, tolerance, politeness, equity, justice and respect for life reportedly held by transformational leaders substantiate a link between transformational leadership and teleology. Similarly, the relationship of transformational leadership to deontological theory is supported by the respondents' beliefs that instrumental values such as caring, commitment to ethical behaviour and terminal values such as love, understanding and respect for life underpin transformation leadership. 
Is a transformational leadership style always "right"? Comments from respondents suggest that in an ideal situation with a coherent organization, the right staff, a leader with the right abilities, and access to the right knowledge and information it can work very well. Without these, when an inspirational leader takes advantage of the trust of staff, when there is a change in the organization situation (for example, a crisis or a change in leadership) then it is probably not right.

Is there an implied approach to ethics in transformational leadership? Yes, but transformational leadership, of itself, is not ethical. The results of this study would suggest that leaders' values are more important than the operationalisation of the management practices suggested by transformational leadership theory, in driving ethical behaviour among leaders.

\section{Conclusion}

Some of the limitations of this study are the relatively small number of leaders interviewed, discrepancies in the participants' knowledge of transformational leadership, and that the type of study did not allow statistical analysis of the relationships. Nevertheless, there is no doubt that those interviewed had no difficulty in responding and identifying values, ethical behaviours and leadership practices (even if they did not always appreciate the meaning of transformational leadership). As such, it is a useful starting point that confirms a relationship between values and ethics and transformational leadership.

Elliott (2002, p.32) stated "The extent to which leadership actively aligns actual and espoused values of an organization within the framework of a strategic vision probably accounts for one quarter of all organization behaviour." In these times with increasing numbers of accounts of unethical business practices in the press, the significance of our leaders' ethics and values to society cannot be ignored.

Values and ethics are important topics for the leaders of organisations because they clarify the moral obligations and ethical responsibilities of the leaders who make business decisions. Ethics refers to more than compliance with laws and regulations such as those applying to occupational health and safety regulations, sexual harassment or insider trading. Criteria based solely on legality are insufficient to effectively inform managers about how to respond to complex crisis that have far-reaching ethical consequences. Complex moral problems require an understanding and concern for ethical values fairness, justice, and due process to people, groups and communities. However, in regard to transformational leadership, the conclusion from the results of this study is that leaders' values are more important in driving ethical behaviour among leaders, than the operationalisation of the management practices suggested by transformational leadership theory. This study contributes to the debates on these issues.

\section{References}

Avolio, B. J., \& Bass, B. M. (1995). Individualised consideration viewed at multiple levels of analysis:

A multi-level framework for examining the diffusion of transformational leadership. Leadership Quarterly, Vol. 6(2), pp.199-218.

Bass, B. M. (2000). Authentic and pseudo-transformational leadership. Paper presented at the Presentation to the Business Ethics Research Unit Seminar, Victoria University.

Bass, B. M., \& Avolio, B. J. (1997). Full range leadership development:Manual for the Multifactor Leadership Questionnaire. Palo Alto: Mind Garden, Inc.

Bass, B. M., \& Steidlmeier, P. (1999). Ethics, Character, and Authentic Transformational Leadership Behaviour. Leadership Quarterly, Vol. 10(2), pp. 181-217.

Bass, B. M. (1985). Leadership and Performance Beyond Expectations, New York, The Free Press. Blake, R.R. \& Mouton, J. S.(1985). The Managerial Grid 111. Houston, Gulf Publishing. 
Boehnke, K. Bontis, N. Distefano, J.J., DiStefano, J.J. (2003). Transformational leadership: an examinationof cross-national differences and similarities. Leadership \& Organization Development

Journal, Vol. 24(1), pp. 5-15.

Cockerell, R. and Armstrong, 2000 A. Ethical Climate and the Quality of Working Life., Paper presented to the AICE99 Conference, Swinburne University of Technology, Lilydale, July 14.

Dubin, R. (1978). Theory Building in Applied Areas. In Dunnette, R. Handbook of Industrial and Organisational Psychology. pp. 17-39.

Elliott, R. H., Armstrong, A., \& Alder, J. (2001, 5 April 2001). Triangulation Approaches to Measuring Ethical Leadership. Paper presented at the School of Management Seminar, Victoria University.

Elliott, R. H., \& Engebretson, K. (2001). Chaos or Clarity: Encountering Ethics ( 3 ed.). Melbourne: Wentworth Falls:Social Science Press.

Feather, N. (1986). Cross-cultural studies with the Rokeach Value Survey: The Flinders program of research on values. Australian Journal of Psychology, Vol. 38 (1), pp. 269-283.

Feidler, F. E. (1967). A Theory of Leadership Effectiveness. New York: McGraw Hill.

Fishbein, M. \& Ajzen, I. Belief, attitude and Behaviour: An introduction to Theory and Research. Reading, Massachusetts: Addison-Wesley.

Francis, R.D. (2000) Ethics and Corporate Governance: An Australian Handbook. Sydney: University of New south Wales.

Francis, R.D. \& Armstrong, A. (2001). Ethical Commitment Guaged from Company Annual Reports. Australian Journal of Professional and Applied Ethics, Vol. 2 (1), pp. 54-61.

Giampetro, M. A., Brown, T., Browne, M. N., \& Kubasek, N. (1998). Do we really need more leaders in business? Journal of Business Ethics, Vol. 17(5), pp. 1727-1736.

Hamden-Turner, C., \& Trompenaars, F. (1993). The Seven Cultures of Capitalism: Value Systems for Creating Wealth in the United States, Britain, Japan, Germany, france, Sweden, and the Netherlands. London: Piatkus.

Herman, S., \& Egri, C. P. (2002). Triangulation in Action: Integration of Qualitative and Quantitative Methods to Reach Environmental Leaderships. In K. W. Parry \& J. Meindl, R. (Eds.), Grounding Leadership Theory and Research: Issues, Perspectives, and Methods (Vol.1, pp. 129-148). New York: Information Age Publishing Inc.

Hersey. P. \& Blanchard, H.K. (1993). Management of Organisational Behaviour: Utilizing human resources.Englewood Cliffs, Prentice Hall.

Hofstede, G. (1980). Culture's Consequences: International differences in Work-Related Values. California: Sage.

Howell, J. M., \& Avolio, B. J. (1992). The ethics of charismatic leadership: submission or liberation? Academy of Management Executive, Vol. 6(2), pp. 43-54.

Kabanoff, B. \& Daly, J.P.(2000). Values espoused by Australian and US Organisations. Applied Psychology: An International Review, Vol. 49(2), pp. 284-314

Kuhnert, K. W. (1994). Transforming leadership: Developing people through delegation. In B. M. Bass \& B. J. Avolio (Eds.), Improving organisational effectiveness through transformational leadership pp. 10-25. Thousand Oaks: Sage.

Lagen, A. (1998). Recognising the Value in Values. HR Monthly.August 3, pp. $28-29$.

Lasswell, H.D., Lerner, D.\& Pool, I. de Sola (1952) The Comparative Study of Symbols. Standford:Stanford University Press.

Muenjohn. N. and Armstrong, (2001). A. Cross-cultural leadership: Identifying the key leadership behaviour of Australian expatriates. Hawaii conference on Business, Hawaii, University of Hawaii.

Muenjohn, N. and Armstrong, A. 2007 Transformational Leadership: the influence of culture on the leadership behaviours of expatriate managers, International Journal of Business and Information, Vol 2 (2) 265-283.

Muenjohn, N. and Armstrong, A. 2008 Evaluating the structural validity of the Multifactor Leadership questionnaire (MLQ), capturing the leadership factor in transformational-transactional leadership. Contemporary Management Research, Vol. 4, No.1, March. 
Northouse, P. G. (2001). Leadership Theory and Practice ( Second ed.). Thousand Oaks: Sage Publications Inc.

Parry, K. W., \& Proctor, S. B. (2001). Perceived integrity of transformational leaders in organisational settings. Journal of Business Ethics, In press.

Roberts, C A (2002). Grounded theory: Creating Valued leadership Research through partnering In W. Parry. Ken \& j. Meindl, R. (Eds.), Grounding Leadership theory and Research: Issues, Perspectives and Methods Vol. (1), pp. 149-158). New York: Age Publishing Inc.

Rokeach, M. (1973). Understanding Human Values. New York: Free Press.

Sarros, J.C. \& Butchatsky, O. (1995) Leadership. Sydney: HarperCollins

Stoghill, R. M. (1974). Handbook of leadership:A survey of theory and research. Vol. 25. New York: Free Press.

Yukl, G. (1998). Leadership in Organisations. New Jersey: Prentice hall. 
Table 1. Positive outcomes associated with the four transformational dimensions

\begin{tabular}{|c|c|c|c|c|}
\hline & Idealized Influence & $\begin{array}{c}\text { Inspirational } \\
\text { Motivation } \\
\end{array}$ & $\begin{array}{l}\text { Intellectual } \\
\text { Stimulation }\end{array}$ & $\begin{array}{c}\text { Individualized } \\
\text { consideration }\end{array}$ \\
\hline $\begin{array}{c}\text { Positive } \\
\text { effects } \\
\text { associated } \\
\text { with each } \\
\text { dimension }\end{array}$ & $\begin{array}{l}\text { Absolutely credible } \\
\text { Sets high intellectual } \\
\text { standards } \\
\text { Makes you think that } \\
\text { work is worthwhile } \\
\text { Happiness: feeling of } \\
\text { being wanted } \\
\text { Leading by example: } \\
\text { ensures the future } \\
\text { pride staff want to } \\
\text { feel about } \\
\text { themselves } \\
\text { Builds confidence } \\
\text { Articulates clearly } \\
\text { commands to staff } \\
\text { Not establishing or } \\
\text { imposing objectives } \\
\text { is immoral } \\
\text { Leader leads by } \\
\text { example }\end{array}$ & $\begin{array}{l}\text { People who are } \\
\text { stretched } \\
\text { respond better } \\
\text { Cannot make } \\
\text { people do what } \\
\text { they do not } \\
\text { want to do }\end{array}$ & $\begin{array}{l}\text { Wise delegation is } \\
\text { effective }\end{array}$ & $\begin{array}{l}\text { Recognised } \\
\text { individuality } \\
\text { and } \\
\text { promoted } \\
\text { individual } \\
\text { development } \\
\text { Forgiveness and } \\
\text { admission } \\
\text { better than } \\
\text { punishing }\end{array}$ \\
\hline
\end{tabular}

Table 2. Values, behaviours and outcomes associated with the worst leadership styles

\begin{tabular}{|c|c|c|c|}
\hline Leaders Values & Behaviours & Outcomes for leaders & $\begin{array}{c}\text { Outcomes for } \\
\text { followers }\end{array}$ \\
\hline $\begin{array}{l}\text { - Desire for control/ } \\
\text { - power at all costs } \\
\text { - Motivation of greed } \\
\text { - Inhumane } \\
\text { - Disregard or } \\
\text { people's welfare } \\
\text { - No recognition that } \\
\text { ethical principles } \\
\text { apply }\end{array}$ & $\begin{array}{l}\text { - Over control } \\
\text { - Not caring } \\
\text { - Out of touch/ did not } \\
\text { listen } \\
\text { - Some lack courage } \\
\text { - Lack of trust } \\
\text { - No understanding of } \\
\text { ethics } \\
\text { - Instead of "how well } \\
\text { I can do" is "protect } \\
\text { my back" } \\
\text { - Won't make a } \\
\text { decision } \\
\text { - Sits on the fence } \\
\text { - Discusses ad } \\
\text { nauseam } \\
\text { - Believes everyone } \\
\text { agrees }\end{array}$ & $\begin{array}{l}\text { - Egomania } \\
\text { - Earns disrespect } \\
\text { - Seen to whinge about } \\
\text { current situation } \\
\text { - Creates conflict, } \\
\text { infighting } \\
\text { - Uncertainty } \\
\text { - Loss of energy } \\
\text { - Stress } \\
\text { - Constant state of } \\
\text { vigilance } \\
\text { - Exaggeration of } \\
\text { problems because } \\
\text { unable to deal with } \\
\text { them } \\
\text { - Puts pressure on others } \\
\text { - Tries to impose a view } \\
\text { without discussion } \\
\text { - Confers only with } \\
\text { those who agree } \\
\text { - Tries to impose views } \\
\text { without thought } \\
\text { - Fails to talk with } \\
\text { people and get them on } \\
\text { board } \\
\text { - Superficial charm } \\
\text { hides objectives }\end{array}$ & $\begin{array}{l}\text { - } \text { Despair } \\
\text { - Anger } \\
\text { - Incredulity } \\
\text { - A wish to change } \\
\text { things } \\
\text { - Non-cooperation } \\
\text { - Collapse of } \\
\text { - } \text { projects } \\
\text { - Lesentment } \\
\text { - } \text { organingation } \\
\text { People } \\
\text { concentrate on the } \\
\text { wrong things } \\
\text { - Destabilizing } \\
\text { - Lack of } \\
\text { commitment } \\
\text { Nothing done } \\
\text { properly }\end{array}$ \\
\hline
\end{tabular}


Table 3. The limitations of transformational leadership

\begin{tabular}{|c|c|c|c|c|}
\hline & $\begin{array}{l}\text { Idealized } \\
\text { influence }\end{array}$ & $\begin{array}{l}\text { Inspirational } \\
\text { Motivation }\end{array}$ & $\begin{array}{l}\text { Intellectual } \\
\text { stimulation }\end{array}$ & $\begin{array}{l}\text { Individualized } \\
\text { consideration }\end{array}$ \\
\hline $\begin{array}{l}\text { Negative } \\
\text { perceptions of } \\
\text { transformational } \\
\text { leadership }\end{array}$ & $\begin{array}{l}\text { Can be too } \\
\text { unified/too } \\
\text { string and } \\
\text { overbearing } \\
\text { (e.g. the } \\
\text { parish } \\
\text { minister) } \\
\text { If the leader has } \\
\text { a wrong } \\
\text { vision, it can } \\
\text { be bad for the } \\
\text { organization, } \\
\text { career and } \\
\text { clients }\end{array}$ & $\begin{array}{l}\text { Time constraints: } \\
\text { "not enough } \\
\text { time to service } \\
\text { the demands of } \\
\text { inspirational } \\
\text { motivation" } \\
\text { Some people are } \\
\text { more influenced } \\
\text { or } \\
\text { susceptible... wea } \\
\text { k, vulnerable } \\
\text { people looking } \\
\text { for hope. } \\
\text { People submit, give } \\
\text { up control of } \\
\text { life, seeking } \\
\text { some meaning } \\
\text { Some people are } \\
\text { not motivated } \\
\text { except by being } \\
\text { told } \\
\text { Managers see it as } \\
\text { losing power } \\
\text { Employees see it as } \\
\text { being dumped on } \\
\text { Leaderless groups } \\
\text { don't work }\end{array}$ & $\begin{array}{l}\text { Goals become } \\
\text { fuzzy and the } \\
\text { direction } \\
\text { indistinct } \\
\text { The leader looks } \\
\text { weak, loses } \\
\text { credibility } \\
\text { Some } \\
\text { organizations } \\
\text { need a strong, } \\
\text { authoritative } \\
\text { leader because } \\
\text { of the nature } \\
\text { of the } \\
\text { circumstances } \\
\text { (e.g. war) } \\
\text { Needs a culture } \\
\text { for it (culture } \\
\text { of “don't } \\
\text { tolerate } \\
\text { mistakes } \\
\text { means no risk } \\
\text { taking, don't } \\
\text { challenge the } \\
\text { protocol) } \\
\text { Get conflict all } \\
\text { the time } \\
\text { Most of the time } \\
\text { is spent } \\
\text { working out } \\
\text { alliances } \\
\text { Some people } \\
\text { expect more } \\
\text { harmony in } \\
\text { decision } \\
\text { making }\end{array}$ & $\begin{array}{l}\text { Depends on the } \\
\text { situation: leader } \\
\text { must make a } \\
\text { decision } \\
\text { Success depends } \\
\text { on the judgment } \\
\text { of the leaders - } \\
\text { which } \\
\text { individual, } \\
\text { when. Are } \\
\text { people there as } \\
\text { individuals or } \\
\text { part of the } \\
\text { team? } \\
\text { Individual } \\
\text { recognition is } \\
\text { good but subject } \\
\text { to the stability } \\
\text { and interests of } \\
\text { the organization } \\
\text { Some } \\
\text { organizations } \\
\text { want their } \\
\text { people to be } \\
\text { conforming - } \\
\text { don't like } \\
\text { differences in } \\
\text { individuals and } \\
\text { aim for a } \\
\text { common culture } \\
\text { Differences are } \\
\text { hard to manage } \\
\text { culture breaks } \\
\text { down if there } \\
\text { are dissenting } \\
\text { pockets in the } \\
\text { organization }\end{array}$ \\
\hline
\end{tabular}


Table 4. Terminal and instrumental values associated with transformational leadership

\begin{tabular}{|c|c|c|}
\hline Values & $\begin{array}{c}\text { Instrumental } \\
\text { (mode of conduct) }\end{array}$ & $\begin{array}{c}\text { Terminal } \\
\text { (end state) }\end{array}$ \\
\hline & $\begin{array}{l}\text { Moral } \\
\text { Integrity } \\
\text { Honesty (with self and others) } \\
\text { Caring/understanding the needs of } \\
\text { others/human role } \\
\text { Fairness } \\
\text { Not doing things in your own interests } \\
\text { Responsible } \\
\text { Respect for People } \\
\text { Inspiring } \\
\text { Able to hold conflicting views } \\
\text { Politeness } \\
\text { Commitment to ethical behaviour } \\
\text { Not needing others to agree with them } \\
\text { Transparency (why you did what you did) } \\
\text { Risk taking } \\
\text { Fearless (in raising issues of concern) } \\
\text { Competence } \\
\text { Holds opinions } \\
\text { Hope } \\
\text { Truthful } \\
\text { Tolerance } \\
\text { Calmness } \\
\text { Personal control } \\
\text { Confident/sure footed } \\
\text { Intellectual mastery } \\
\text { Skilled } \\
\text { Commitment to quality work } \\
\text { Clarity of mind } \\
\text { Facilitative } \\
\text { Accessible } \\
\text { Measured approach } \\
\text { Interpersonal skills }\end{array}$ & $\begin{array}{l}\text { Self-worth/respect } \\
\text { Dignity } \\
\text { Pride } \\
\text { Survival } \\
\text { Happiness } \\
\text { Buoyancy } \\
\text { Involvement } \\
\text { Achievement } \\
\text { Respect for Life } \\
\text { Love } \\
\text { Clarity of mind } \\
\text { Clarity of interpersonal skills } \\
\text { Equity } \\
\text { Justice } \\
\text { Understanding }\end{array}$ \\
\hline
\end{tabular}

Table 5. Positive Values associated with transformational leadership and three ethical theories.

\begin{tabular}{lll}
\hline Ethical Theory & \multicolumn{1}{c}{$\begin{array}{c}\text { Values } \\
\text { Instrumental } \\
\text { (competence }\end{array}$} & \multicolumn{1}{c}{$\begin{array}{c}\text { Terminal } \\
\text { (end state) }\end{array}$} \\
\hline Egoism & Honesty with self & $\begin{array}{l}\text { Happiness } \\
\text { Dignity } \\
\text { Pride } \\
\text { Equity } \\
\text { Teleology }\end{array}$ \\
& Truthfulness & Justice \\
& Tolerance & Respect for Life \\
Politeness & Understanding \\
Caring & Love \\
& Commitment to ethical & Respect for life \\
\hline
\end{tabular}

